\title{
MACROECONOMIC RISKS: CLASSIFIED FEATURES, METHODS OF MEASUREMENT, MITIGATION PATTERNS
}

\author{
Yurii Paida', Yaryna Andrushko², Olena Iliushyk ${ }^{3}$
}

\begin{abstract}
The article deals with the essence, factors, and patterns of macroeconomic risks mitigation. The purpose of the paper is to summarize and present a classification of systemic risks, to analyse principles and methods of macroeconomic risks evaluation. The methodological basis of the study is general scientific and special methods of cognition. The most extended analysis of systemic risks not only from the perspective of geographical and historical aspects but also in the context of modern economic processes is carried out. Results of the research prove that in the context of formation of a new economy of Ukraine and approval of the practice of timely prevention and mitigation of macroeconomic risks in accordance with imperative of modern time, it is necessary to: 1) give real state priority to the most advanced educational technologies. While providing maximum broad and equal access of youth to education, we should have the program for search and practical support of national intelligence phenomena in place; 2) create conditions for rehabilitation and advanced development of innovative directions of applied and, first and utmost, polytechnic sciences. It is the task of the state to ensure their financial support and direct employment at enterprises. All-round support of introduction of high-yield venture developments into the production; 3) secure efficient state protection of intellectual property, create legislatively the conditions for commercial usage of innovative achievements within the country; 4) encourage with maximum efficiency return of high-level engineers and blue-collar workers to the technological area; breathe new life into the system of professional and technical schools where information and programming professions prevail and which graduators would be engaged with priority into operations in unique productions; 5) create modern information market, allround support of introduction of a unified information field. Learning and striving to satisfy human needs without placing systemic risks on future generation being on the Earth should become the core principle of a civilizational development. Value/originality. We may lay down an essential principle of civilizational regulation of systemic risks when each state, specifically the international community, should set up (subject to all complexities of practical implementation) regulating constants, rules, and bans of such contents and in such direction to have business or entrepreneurial activities carried out ultimately in the risk-related mode, which would cause no detrimental effect on the economy as whole.
\end{abstract}

Key words: systemic risks, macroeconomic risks, risk monitoring, VAR-model.

JEL Classification: A1, E00, E2, E37

\section{Introduction}

Rising increment, ambiguity, and uncertainty around phenomena and totality of non-linear, unbalanced processes in economic, entrepreneurial, and business activities are more and more inherent for fundamental economic transformations when risky situations become their intrinsic feature. Frequency and gravity of macro-risks effects on the global economic stability have ramped up dramatically whereas capabilities of existing systems for their mitigation and management, which would adequately and efficiently counteract potential adverse effects and threats, have shrunk markedly.

Though physical time flows as many thousand years ago, economic timing differs in its entirety; macroeconomic time runs faster increasingly than one hundred or ten years ago. Therefore, content correctness

\footnotetext{
Corresponding author:

${ }^{1}$ Kharkiv National University of Internal Affairs, Ukraine.

E-mail: vovo4ka23@ukr.net

ORCID: http://orcid.org/0000-0002-6424-6419

${ }^{2}$ Lviv State University of Internal Affairs, Ukraine. E-mail: YarunaAn@hotmail.com

ORCID: http://orcid.org/0000-0003-1741-8625

${ }^{3}$ Lviv State University of Internal Affairs, Ukraine.

E-mail: oilyushyk@ukr.net

ORCID: http://orcid.org/0000-0002-4619-5785
} 
requires the most extended analysis of systemic risks not only from the perspective of geographical and historical aspects but also in the context of modern economic processes. It is clear that risks of natural anomalies could cause (and have already caused) thumping damages to the economy. The above evidence explains why it is important to respond timely to potential and existing risks inherent for economic development of every country and especially Ukraine.

The purpose of the article is to summarize and present a classification of systemic risks, to analyse principles and methods of macroeconomic risks evaluation.

\section{The essence of macroeconomic risks}

Macroeconomic risk is rather a complex and multidimensional phenomenon that in turn determines the expediency of its analysis from various perspectives and hence the possibility of the existence of many definitions in sense of categories. Double aspect of macroeconomic phenomena, i.e. competition and monopoly, innovation and conservatism, entrepreneurship and routine, professionalism and incompetence, greed for financial (and not only) gain with ignoring moral and ethical principles, leaves its stamp on the essence and occurrence of macroeconomic risks.

Special researches demonstrated that macro-risks themselves ranked fifth in the list of ten visualized uncertainties accompanying social being (Bazilevich \& Ilin, 2010). Herewith macroeconomic risks (their nature, essential features, factors of origin, volatility and permanency of demonstrations) remain the less explored. This obviousness also necessitates substantial intensification of scientific impact on the processes of exploration and analysis of macroeconomic risks.

Therefore, the subject-matter of our analysis is not segment-specific (currency, price, banking, deposit, credit, exchange, portfolio, index, tax etc.) risks but rather macroeconomic risks realizing in the economic policy and derivatively appearing in various segments.

For this reason, the integrated approach makes it possible to understand the nature, content, and potential effects of macroeconomic risks. It is fair to say that each macroeconomic risk is systemic in terms of its essence and scope of influence, however not in every instance systemic risk is purely economic in its nature. Several macro-risks come under the influence of endogenous factors (instability of legal and regularity support, volatile shifts in existing levels of competitiveness, permanent demand fluctuations etc.).

Conceptually inconsistent and erroneous economic theories contributing to mistakes of the institutional policy nationwide are one of core reasons for macroeconomic risks of systemic nature. For example, neoliberalism as a cult pillar of the economic policy and market orthodox ideology of past decades generated on permanent basis macroeconomic risks not only in the most important areas and segments of national economies, but in global terms as well. Underestimation of importance of unbiased and systemic interpretation of macroeconomic risks in researches (in such context, it is not about journalism and newspaper publications) triggers situations when actual dependencies and relations are out of sight. Thus, it is current practice to use by inertia "quotations-nomads", true meaning of which is long forgotten or distorted. At the same time, the picture of pressing developments and processes is beclouded giving rise to threats of actual but not fancied risks. Within the framework of fuzzy definition of risks and their potential types, the possibility of their mitigation, much less before-the-fact prevention, becomes increasingly conditional.

If evolutionary transformations in the economy could be assessed in whole as positive, then rather endangering changes occur in ecosphere and natural environment. Aggressive rich soil erosion, deforestation, large-scale depopulation of territories, pollution of rivers and lakes with freshwater becoming of absolute scarcity etc. appeared as undesirable effect of human management and being on the Earth. Nowadays such human activities predominate when ecological and technologyrelated risks correspond directly with economic ones making frequently their valuable details. Therefore, state regulation of ecological and economic development is of high relevance today (Biloskurskyi, 2017).

We determine macroeconomic risk as a complex category reflecting such essential features as increment, volatility, conflict, multi-criticality, fuzziness, and uncertainty in economic relations. At the same time, existing macroeconomic relations often exclude adequate response of authorized administrative bodies and business entities concerned in order to make optimum choice from the number of alternative riskrelated options to obtain the most probabilistically desired ultimate result. Intended probabilistic economic result is achieved (as it should be), on the one part, through the timely prevention or mitigation of possible detrimental effects on macroeconomic situation but, on the other part, provides for implementation in the national economy, first of all, effective management, i.e. flexible organizational and management activities.

\section{Principles and methods of macroeconomic risks}

Transformation of scientific views and theoretical generalization on macroeconomic risks demonstrates bipolar views and positions. On the one part, we have scientific approach, which theoretical founders represent that the whole system of economic being is the result of intelligent design (Reinert, 2011; Calomiris \& Haber, 2017; Sargent, 2008). Such a position is observed in theoretical principles and trends of creationism asserting that extended tail of events and phenomena 
may be explained and should be perceived as the result of existing intelligent preconditions. Meanwhile authors of the given theory acknowledge that economic future and, first, processes of macroeconomic development should be generated and regulated proactively (Sargent, 2008). It is worth mentioning that one of the authors of the given theory Thomas J. Sargent obtained Nobel Prize in Economics in 2011.

It is quite enough to know and understand that macroeconomic systems are filled to the brim with systemic risks. At the same time, it is of high relevance to be equipped with top-quality theory, i.e. to know why one or another pain points (risks) appear and which methods may be used to mitigate their adverse effects (Kovalchuk \& Kovalchuk, 2012). It is the analysis, assessment of outcomes and challenges of macroeconomic development and related risks, which are in special focus of highly respected public actors (Gaidutskyi, 2017).

For many decades, scientific analysis of macroeconomic risks, especially mechanisms and methods of their prevention and mitigation has drawn upon extremely formalized fundamentals. Mathematical formalization of macroeconomic developments and processes provoking ultimately perceptible (negative in their nature) external effects became one of such movements. However as time passed, it became more apparent that mathematical econometric theory does not result in detection of universal macroeconomic behaviour. To the contrary, suggested economic and mathematical schemes frequently and successfully draw a veil over their essential amorphous state and predictable dysfunctionality. Regular occurrence of crisis phenomena is not provided for in any mathematical models of "general equilibrium" and this challenges necessity of their further specification.

Macroeconomic world is in turbulent condition and attempts to set up mathematical doctrines of its equilibrium are doomed to fail. Dynamism of social structure, financial markets, technologyrelated transformations prove that macroeconomic development is of non-linear nature, i.e. has much of uncertainty and expressed unbalance. At the same time, the main driving component of macroeconomy "capital of spirit and will", i.e. human activities, more and more requires intergovernmental (global) influence.

It turned out that liberalism, as a foreign benchmark for institutional policy does not correlate to the Ukrainian economic reality by any means. Neoliberal economic theory did not withstand the test of time and practice since the implementation of its recommendations does not make conditions for sustainable economic development on global terms. If theory turns into doctrine, doctrine - into dogma, and dogma - into inadequate economic policy then it is macroeconomic practice, which pays the price. It appeared that market fundamentalism definitely provokes systemic risks demonstrating two phenomena in parallel, i.e. unregulated and, therefore, sizeable inflation of administrative and regulatory decisions and persistent slowdown of macroeconomic indicators.

However, large-scale crisis evidences did not become actual warning for the Ukrainian authorities. Not least because of this fact, Ukraine enjoys "the image" of the state locating in the centre of Europe only territorially but not in terms of criteria of economic development, purity of financial and credit relations, legal culture etc. This macroeconomic situation is just an explicit demonstration of consequences of direct disregard of systemic risks (not least because of being brought from outside) interlaced into the Ukrainian state policy. A causal contradiction between "grand theory" and practice of economic being is one of the factors of existing macroeconomic risks. Therefore, we may say about two-in-one reason for existing macroeconomic risks, on the one part, wrong theoretical basis and orthodoxy of institutional policy pressed from outside, on the other part.

In order to obtain desired funding from foreign organizations, canonical macroeconomists representing interests of IMF and the World Bank justify theoretically abstract models not associated with nuts-and-bolts realities overfilled with systemic risks. According to the Nobel Memorial Prize winner Mr. Joseph Stiglitz who used to hold the position of the First Vice-President of the International Bank for Reconstruction and Development (1997-2000), "our attention is drawn away from real-life problems and we move towards wrong decisions" (Stiglitz, 2002). The scientist pointed out to disregarding in recommendations of representatives of the Washington Consensus of "systemic risks that to the great extent determined the transformation of young states to the Wild World with non-controlled markets, dramatic GDP downturn and impoverishment of population" (Stiglitz, 2014). The danger is also that wrong theoretical postulates underlying for current economic policy and taken for steadfast implementation in the form of laws and regulations carry the potential systemic risks.

It is essential to realize that the key principle of civilizational regulation of systemic risks (prevention or mitigation of potential adverse effects) provides for that each economic system would strive to establish regulating constants, rules and prohibitions of such nature and in such direction to have business or entrepreneurial activities performed in the long run in the way that would give rise to and cause no detrimental impacts both locally and nationwide and internationally. However, unfortunately, the given important postulate is not always considered (Calomiris \& Haber, 2017).

While mitigating macroeconomic risks, collateral systems become more and more meaningful that represent themselves rules and procedure for selection, evaluation and monitoring, movement, and usage of all- 
kind assets in order to mitigate macroeconomic risks. Implementation of the collateral system corresponds to the international standards and the world best practices because its formulae are adopted to the great extent from foreign legal systems; by this very process of increasing efficiency of the infrastructure of the corresponding segment at the financial market is inspired.

The complexity of analysis of potential gains or threats associated with the timely and qualitative level of measuring and evaluating macroeconomic risks is explained largely by the fact that the risks cover the number of principal structural elements in key areas and segments of the national economy, as well as the banking system, securities market, stock market etc. These are exactly stock markets, which demonstrate the most visible volatility, i.e. the broad magnitude of variations of asset value, and hence the existence of socalled portfolio risks.

\section{Macroeconomic models of mitigating economic risks}

Nobel Memorial Prize winner Mr. William F. Sharpe made a stand for the model of portfolio risks based on an evaluation of capital assets, which was criticized by practicing men. "Some practicing men argue that CAPM (Capital Asset Pricing Model) disannulled efficient-market hypothesis. CAPM is not the curiosity of theoretical studies with doubtful empirical confirmation. It became the component of complex strategies for institutional portfolio management" (UAFR, 2011).

Mitigation of macroeconomic risks is provided to a great extent through the implementation of macroeconomic models. Value-at-Risk (VaR) model has been the most widely accepted methodology for market risks evaluation. VAR may be perceived literally as "risk value" or "risk measure". VAR estimation model is used as the basis for reserve capital calculation. For this model, requirements to the volume and size of the reserve capital (V) were calculated as the maximum of two values: a) present value VAR (VARt); b) average VAR for previous two months (60 days) multiplied by coefficient with the value from 3 to 4 . A base formula for such calculations is as follows:

$$
\mathrm{V}=\lambda^{*} \max \left\{\mathrm{VAR}_{\mathrm{t}}, 1 / 60 \sum_{\mathrm{i}=1}^{60} \mathrm{VAR}_{\mathrm{t}-\mathrm{i}}\right\}, 3 \leq \lambda \leq 4
$$

Herewith the value of $\lambda$ factor depends on the accuracy of daily forecasting of the model for the previous periods.

With the help of VaR-based modelling, it becomes possible to forecast and evaluate risks at least in 4 directions: first, "internal monitoring of market risks" may be carried out in several measurements: in terms of issuer's reliability, class of financial assets, adequacy of aggregate portfolio and financial capacities of a contracting party etc.; secondly, VaR system enables "external monitoring" when a general investor may receive a forecast on quality of portfolio assets of external investors and thus estimate investment risk measure; thirdly, VaR may be used for the measurement of hedging efficiency, i.e. determine how activity of a particular hedge-fund achieves strategic goal - actually insures against financial risks; fourthly, with the help of VaR-modelling monitoring of expediency of respective agreements on potential transactions is carried out.

Duly modelled macroeconomic risk should be implemented in a corresponding economic strategy, which incorporated smoothly into the state economic policy that in such a manner creates objective necessity to identify, analyse, measure, and manage risk in activities of business entities (in particular, determination of required and sufficient conditions for care and restraint in relation to economic risk) and hence create favourable environment for mitigation of adverse effects both of local and macroeconomic nature.

Collateral systems act as a critical tool of mitigation of macroeconomic risks. Collateral systems represent themselves rules and procedure for selection, evaluation and monitoring, movement and usage of all-kind assets in order to mitigate macroeconomic risks. Understanding of collateral system correlates to the international standards and the world best practices because its formulae are adopted to the great extent from foreign anti-risk practice. Experience has proven that various options of designing collateral systems are initiated and implemented most of all by Central Banks (Chailloux, Gray \& McCaughrin, 2008).

It is worth mentioning about those financial risks arisen while generation and placement of exchange reserves of our state. The huge risk is that the National Bank of Ukraine doesn't hold exchange reserves in Ukraine but place them in paper format within the USA. This model is the most efficient for financial beneficiaries, which put borrowed reserves into circulation for their own benefit. Assuming Randy factor (taken as the basis for calculation of the volume of accepted exchange reserves) half as large exchange reserves than we have today would be sufficient for Ukraine. All attempts to criticize soundly and scientifically explicitly risky and misguided NBU policies on placement and usage of exchange reserves meet with their persistent neglect (Economika Ukrainy, 2014). Macroeconomic risk of losing by dollar its exclusive role of global equivalent (world currency) in the international arena becomes absolute. Proactive development of cryptocurrency market turns to be its precursor.

At the same time, the idea of innovative modernization embedded into specific strategy could serve an alternative to seemingly desperate Ukraine's lagging behind in the world races for civilizational priorities. The state of Ukraine and the national economy possess all prerequisites for the successful launch of 
the forward-thinking model, i.e. concentration of public potential, available economic and social resources in priority directions of high-technology development. Just embodying in practical terms the idea of the random creation of innovative segments (islands-technopolises) of advanced development; we can build up the strategy of the national economy's development, which would gain fundamental and qualitative differences as compared to the existing one.

Such financial tool as oversight may be sizeable in mitigating economic risks since it expresses the entirety of relations arising in relation to macroeconomic operational capabilities of payment and settlement systems serving the national economy and the block of international economic relations specified by the state. Exercise of oversight is of paramount importance for the national economy because three interrelated macroeconomic sectors have already been formulated and developed nationwide: a) budget area which subjects and at the same time objects of payments and settlements are state authorities and institutions; b) corporate and so-called municipal area where subjects of payment and settlement relations and authorities of local self-government, municipal enterprises etc. play the role of subjects and participants of payments and settlements; c) households and all solvent population of the country which in some way or another are involved by the system of payments and settlements.

While mitigating macroeconomic risks, collateral systems become more and more meaningful. These systems represent themselves rules and procedure for selection, evaluation and monitoring, movement and usage of all-kind assets in order to mitigate macroeconomic risks. Since the implementation of the collateral system corresponds to the international standards and the world best practices because its formulae are adopted to the great extent from foreign legal systems, by this the level of credibility to corresponding financial and crediting tools is increased and the very process of efficiency upturn of the infrastructure of the national market is inspired.

\section{Strategic development of the national economy}

Our scientific analysis confirmed the opinion of individual political leaders, who stand the ground of fundamental changes in the basic paradigm of the strategic development of the national economy. To start with, it relates to so-called catching-up modernization, which in fact has nothing to do with civilizational prospects. For this model out-of-date, over costly and environmentally unfriendly technologies prevail. Under such circumstances, there exists a chronic and steady trend to lagging behind general civilizational standards. The policy of so-called catching-up modernization should be replaced with the strategy of advanced development. The risk of implementing this very strategy is that state regulatory agencies do not provide for and single out first and utmost in the economic strategy the directions of an innovative development containing blast effects. This concerns those industries and productions, which may generate innovative blasts for the national economy. For this purpose, it is necessary to introduce the practice of concentration of financial resources and organizational and management efforts exactly on innovative growth zones.

Major economic risks are produced in the area of shadowing and money laundering (Kovalchuk, 2017). The most representative factors, which give rise to macroeconomic risks in the area of illegally-yearned income laundering are as follows: first, over-shadowing of economic relations in business and entrepreneurship sectors; secondly, spread of corruption and bribe-taking in the system of state, executive, law-enforcement, and judicial authorities; thirdly, inadequate activities of subjects of primary and state financial monitoring according to international standards for financial activity regulation; fourthly, low transparency of activities of regulatory and supervisory authorities. In addition to this, the accumulation of macroeconomic risks boosting the processes of illegally-yearned income laundering is more and more explained by usage of the latest information and communications technologies and Internet-networks (Gates, 2000).

It is high time to start prompt implementation of NBIC-convergence model, i.e. co-evolution of nano-, bio-, info-, and cognitive theories. However, the complexity is that a new generation of innovative technologies conveys a huge charge of various and practically unexplored risks, which prevention and mitigation require monumental financial expenditures. The first decades of XXI increasingly generate understanding that it is unpromising to stay in the routine inertia mode, i.e. while enjoying industrial epic of XX-century technological development undertake languid attempts to catch those who move away rapidly from the era passed and for the sake of advanced development make efforts focused on the latest and innovative achievements. Today the common standard of reforms should be replaced with the concept of systemic rehabilitation and innovative development with bringing in parallels under it the essence and contents of the state economic policy. It is not a coincidence that systemic modernization is nowadays the most acceptable strategic aspect, which actually disowns discredited notion of reforms. Innovative modernization should not be limited to technological borrowings but should be oriented on revolutionary institutional changes.

Radically new phenomenon emerging globally and called the knowledge-based economy is a strategical factor of declining detrimental effects of macroeconomic risks. Origin and formation of a new economy, in addition to other advantages, ramp up possibilities of positive impacts of systemic risks on appropriate segments 
and areas of production relations. The notion of a new economy or economy of knowledge shall encompass key trends of changes in production, information and communications supplements to organizational and management systems, intensive generation of multiservice networks and the spread of Internetnetworks. The sensible increase of knowledge-intensive, high-technological companies producing risk projects, as well as methods of mitigating adverse effects are features of a new economy. A new economy encapsulates three mutually intersecting areas - particularly education, science, and innovative technologies. Transformation of knowledge, information, ideas, and symbolic images into dominant property item does not simply adjust but change radically the state of affairs, i.e. these property components may be reproduced endlessly; they may be used in the most remote areas simultaneously. These factors, instead of materialized property (as today), become determining feature of a new status of the real economy. Moreover, owing the possibility to mitigate adverse signs of macroeconomic risks is intensified.

In conclusion, we may lay down an essential principle of civilizational regulation of systemic risks when each state, specifically the international community, should set up (subject to all complexities of practical implementation) regulating constants, rules and bans of such contents and in such direction to have business or entrepreneurial activities carried out ultimately in the risk-related mode, which would cause no detrimental effect on the economy as a whole.

\section{Conclusions}

In the context of the formation of a new economy of Ukraine and approval of the practice of timely prevention and mitigation of macroeconomic risks in accordance with the imperative of modern time, it is necessary to: 1) give real state priority to the most advanced educational technologies. While providing maximum broad and equal access of youth to education, we should have the program for search and practical support of national intelligence phenomena in place; 2) create conditions for rehabilitation and advanced development of innovative directions of applied and, first and utmost, polytechnic sciences. It is the task of the state to ensure their financial support and direct employment at enterprises. All-round support of introduction of high-yield venture developments into the production; 3 ) secure efficient state protection of intellectual property, create legislatively the conditions for commercial usage of innovative achievements within the country; 4) encourage with maximum efficiency return of high-level engineers and blue-collar workers to the technological area; breathe new life into the system of professional and technical schools where information and programming professions prevail and which graduators would be engaged with priority into operations in unique productions; 5) create a modern information market, all-round support of introduction of a unified information field. Learning and striving to satisfy human needs without placing systemic risks on future generation being on the Earth should become the core principle of a civilizational development.

\section{References:}

Bazilevich, V., Ilin, V. (2010). Metaphizika economiki [Metaphysics of economy]. 2-d ed., revised and corrected. Kiev: Znannia, 925 p. (in Ukrainian)

Biloskurskyi, R. R. (2017). Derzhavne reguliuvannia natsionalnogo ecologo-economichnogo rozvytku [State regulation of the national ecological and economic development] (Thesis for academic degree of Doctor of Economics), Kyiv: National Academy of Management, $41 \mathrm{p}$.

Chailloux, A., Gray, S., McCaughrean, R. (2008). Central Bank Collateral Frameworks: Principles and Policies. IMF Working Paper WP/08/222. September 2008.

Charles W. Calomiris, Stephen H. Haber (2017). Fragile by Design: The Political Origins of Banking Crises and Scarce Credit. Moscow: Izd-vo Instituta Gaidara, 720 p.

Danylyshyn, B. M. (1999). Investytsiynyi klimat v Ukraini: factory regionalnykh ryzykiv [Investment climate in Ukraine: factors of regional risks]. Kyiv: RVPS Ukraine, 192 p. (in Ukrainian)

Engle III Robert F. Risk and volatility: econometric models and financial practice. Retrieved from: http://nobelprize.org

Gaidutskyi, P. (2017). Nezabuti reformy v Ukraini [Unforgotten reforms in Ukraine]. Kyiv: DKS-centre, 852 p. (in Ukrainian) Gates Bill (2000). Business @ the Speed of Thought: transl. from Engl. Moscow: Progress, 368 p. (in Russian)

Klinov, V. G. (2017). Sdvigi v mirovoi economike $v$ XXI veke: problemy i perspektivy razvitia [Shifts in the world economy in XXI century: problems and prospects of development]. Voprosy economiki, 7, 114-127.

Kovalchuk. A. (2017). Borotba z vidmyvanniam brudnykh capitaliv. Mizhnarodni standarty ta natsionalni realii [Fighting against capital laundering. International standards and national realities]. Kyiv: Znannia, 318 p. (in Ukrainian)

Kovalchuk, T. T., Kovalchuk, N. P. (2012). Macroeconomichni ryzyky [Macroeconomic risks]. Kyiv: Znannia, 301 p. (in Ukrainian)

Kovalenko, V. (2011). Finansovi ryzyky ta shliakhy ikh minimizatshii [Financial risks and their mitigation methods]. Kyiv: Znannia, 319 p. (in Ukrainian) 
Kovanchuk, T., Cherniak, V., Shevchuk, V. (2009). Aktualitety polityky rozvytku [Actuality of the policy of development]. Kyiv: Znannia, 326 p. (in Ukrainian)

Reinert, S. (2011). How Rich Countries Got Rich... and Why Poor Countries Stay Poor: transl. from Engl. Moscow: GU VSHE, 384 p. (in Russian)

Sargent, T. J. (2008). Evolution and Intelligent Design. American Economic Review, 98(1), 5-37.

SOS - v Ukraini neokolonialna model valyutnoyi polityky (2014) [SOS - neocolonial model of exchange policy in Ukraine]. Economika Ukrainy, 10, 4-13.

Stiglitz, J. E. (2014). The innovation enigma Project Syndicate, March 9. Retrieved from: https://www. projectsyndicate.org/commentary/

Stiglitz Joseph E. (2002). Globalization and Its Discontents. New York, p. 12.

Vitlinskyi, V. V. (2008). Ryzykologia veconomitsi ta pidpryemnytstvi [Riskology in economy and entrepreneurship]. Kyiv: KNEU, 480 p. (in Ukrainian)

Vydatnifinansysty ta suchasna praktyka (2011) [Outstanding financial experts and modern practice].Encyclopaedical dictionary. Kyiv: UAFR, p. 270. (in Ukrainian)

Yermoshenko, M. M. (2011). Upravlinnia ryzykamy vzaemodii strakhovykh kompaniy z bankamy [Management of risks of relations of insurance companies with banks]. Aktualni problemy economiky, 6, 191-200. 